\title{
COMPOSITE ROOFING SECTIONS FOR SUSTAINABLE ENERGY EFFICIENT BUILDINGS
}

\author{
S. Eshwariah ${ }^{1}$, M. Viswanadham ${ }^{2}$ \\ ${ }^{1}$ Chief Engineer, Telangana State Housing Corporation Ltd, Hyderabad, India \\ ${ }^{2}$ Professor, Department of civil Engineering, Jawaharlal Nehru Technological University, Hyderabad, India
}

\begin{abstract}
The construction industry is the largest economic activity of any nation. More than $60 \%$ of counties raw materials, $12 \%$ of regular water is being consumed by the buildings. In addition million tonnes of construction and demolition wastes are generated every year. Natural construction materials are no more freely available and materials produced in large scale industries have become more energy intensive. Sustainable building design aims at durability, economy, reducing pollution and environmental degradation. Locally manufactured products are preferred so that the collective material environment of locality remain a constant and moreover the fuel for transporting the material is saved.A comparative study is made on an alternative composite roofing section of shabad stone+ PCC over RC rafters to a conventional RCC roofing for a single room tenement house. Study is made for strength, stiffness, energy consumption, thermal performance and cost. It is found the alternate section has satisfied the requirements of strength and stiffness and performed well in energy consumption, thermal performance and the cost compared to $R C C$.
\end{abstract}

Keywords: sustainable construction, composite roofing, shabad stone roofing, embodied energy, thermal comfort, affordable housing construction.

\section{INTRODUCTION}

Sustainable development is the development that meets the need of present without compromising the ability of future generations to meet their own needs ${ }^{[4]}$. The goal of sustainable environment is to ensure that every one has secure living environment which promotes health and well being and provision of which does not require an unsustainable level of resource use. Construction is indispensable for development but also a major consumer of natural resources and potential polluter of the environment. Sustainable management of construction resources and control of environmental degradation will require the increasing use of energy efficient and clean technologies, utilising renewable natural resources.

The building materials industry is the major consumer of Global non-renewable energy and mineral sources. The building construction industry, which is the primary infrastructure industry consumes $40 \%$ of materials entering the global economy and generates $40-50 \%$ of global output of GHG emissions and the agents of acid rain ${ }^{[2]}$. Therefore there is concern about the impact of the resource use in buildings on the global environment. The energy not only includes the use of fuels in in production process, and in transporting them to the factory. It also includes the energy used to make and maintain the machinery used in production process

The scarcity and cost of durable building materials is considered as one of the main obstacle for better housing standards. As populations grow and become more urbanised, the soil and vegetable materials on which traditional rural building methods have depended are no longer cheaply or freely available and they are being replaced by processed or factory made materials ${ }^{[1]}$. As a result the produced materials have become too expensive to the poor and likewise large scale industrially produced materials have become energy intensive. Therefore designers and builders have to work on the choice of building materials keeping in view of the total embodied energy of the construction material.

\section{ENERGY AND ENVIRONMENT:}

Over a period of time, construction industry shifted from the use of naturally available materials to the industrially produced materials. Production of these materials has added another problem of environmental pollution. Pollution arising from the production of building materials arises at three levels.

- At local level (under $1 \mathrm{~km}$ ), caused by gasses produced in combustion of fuels, causing health risk to workers and local residents.

- At regional level (up to $100 \mathrm{~km}$ ) pollution can cause climatic modification through thermal effects or persistence of particles in the atmosphere.

- At Global level it is the emittence of greenhouse gasses causing Global warming and other gasses causing acid rains.

The principal measure which can be taken to reduce energy pollution associated with building materials processes is to reduce their total primary energy consumption. Similarly reduction in greenhouse gases is also achieved by fuel substitution. 
Table1. Contributions to green house warming by various gases $^{[3]}$

\begin{tabular}{|l|l|}
\hline Gas & $\begin{array}{l}\text { Contribution to } \\
\text { warming } \\
\text { (percentage) }\end{array}$ \\
\hline Carbondioxide & 50 \\
\hline Methene & 19 \\
\hline CFCs & 17 \\
\hline Tropospheric ozone & 8 \\
\hline Nitrous oxide & 4 \\
\hline
\end{tabular}

\begin{tabular}{|l|l|l|}
\hline Fuel & \multicolumn{2}{|l|}{ CO2 emmisions,Kg/GJ } \\
\hline Coal & 91 & 92 \\
\hline Natural gas & 50 & 55 \\
\hline Oil(petroleum) & 69 & 84 \\
\hline Electricity & & 231 \\
\hline
\end{tabular}

Hence Energy conservation is an important aspect in building design. It is necessary to minimise the total energy consumed during buildings life time. The total energy consumed in building during its life time is generally many times that consumed in its construction.. In most cases the energy embodied in materials of which a house is made will be several times larger than annual consumption of energy in use, so there will be faster return on savings made in construction energy than on equivalent savings made in energy consumption.

Building designers have much control over the total amount of energy embodied in a building, through proper selection of materials than they have over the amount of energy consumed annually in use.

Building materials are responsible for about 20 percent of green house gasses emitted by the building during its life time. Green buildings shall use the products that are nontoxic, reassemble, renewable and/or recyclable wherever possible. Locally manufactured products are preferred so that the collective material environment of locality remain a constant and moreover the fuel for transport of material is saved.

\subsection{Energy Analysis}

Energy analysis is the evaluation of the total quantity of energy which has to be taken from primary energy sources in order to produce a given commodity or service. It includes not only the direct use of fuels in production process but also the amount of fuel used in obtaining the raw materials used in production process and transporting them to the factory. It should also include the energy used to make and maintain the machinery used in production process. The total energy consumed in these ways is called the gross energy requirement of commodity and is expressed in the appropriate energy units.

\subsection{Energy Requirement for Building Materials}

\section{Manufacture:}

Building materials are classified in to four categories based on their energy required to manufacture them as ; high, medium and low-energy materials.

- Very high-energy materials are those with energy intensities above 50GJ/ton.

- High-energy materials are those with energy intensities between 50 and $5 \mathrm{Gj} /$ ton like, Aluminium, steel, plastics, glass and cement.

- Medium-energy materials are those with energy requirements between 0.5 and $5 \mathrm{GJ} /$ ton like, concrete, lime, plaster and building blocks based on cent or lime and fried-dry bricks and tiles and transported Timber.

- Low-energy materials are those with energy requirements less than $0.5 \mathrm{GJ} /$ ton like aggregates for concrete and mortar, natural and artificial pozzolanas, soil and stabilised soil.

Table: 2.1 Comparative energy requirements of building materials $^{[5]}$

\begin{tabular}{|l|l|}
\hline Material & $\begin{array}{l}\text { Primary energy } \\
\text { requirement } \\
\text { GJ/ton }\end{array}$ \\
\hline Very-high-energy & $200-250$ \\
\hline Aluminium & $50-100$ \\
\hline Plastics & $100+$ \\
\hline Copper & $100+$ \\
\hline Stainless steel & $30-$ \\
\hline High-energy & 60 \\
\hline Steel & $25+$ \\
\hline \multicolumn{2}{|l|}{} \\
\hline Lead, zinc & $12-25$ \\
\hline Glass & $5-8$ \\
\hline Cement & $8-10$ \\
\hline Plasterboard & $3-5$ \\
\hline Medium-energy & $2-7$ \\
\hline Lime & $1-4$ \\
\hline Clay bricks and tiles & $0.8-1.5$ \\
\hline Gypsum plaster & $0.8-3.5$ \\
\hline Concrete & $1.5-8$ \\
\hline In-situ & $0.8-1.2$ \\
\hline Blocks & $0.1-5$ \\
\hline Precast & $<0.5$ \\
\hline Sand lime bricks & $<0.5$ \\
\hline Timber & $<0.5$ \\
\hline Low-energy & $15 \mathrm{MJ} /$ Ton \\
\hline Sand, aggregate & $100 \mathrm{MJ} /$ Ton \\
\hline Flyash,RHA,volcanic ash & $220 \mathrm{MJ} /$ ton \\
\hline Soil & \\
\hline \multicolumn{2}{|l}{} \\
\hline Broken stone & \\
\hline Crushed aggregate & \\
\hline \multicolumn{2}{|l|}{} \\
\hline \multicolumn{2}{|l|}{} \\
\hline
\end{tabular}

$1 M J=238.9 k$ cal or $1 \mathrm{Cal}=4.184 \mathrm{~J}$ 


\section{GREEN BUILDING}

The term Green building refers to a structure and using process that is environmentally responsible and resourceefficient throughout a building's life-cycle: from siting to design, construction, operation, maintenance, renovation, and demolition ${ }^{[1]}$. The material required for construction should also meet the requirements of strength, dimensional stability, and thermally efficient. Sustainable Building design should aim at durability, economy and reducing pollution and environmental degradation.

A building designer should have Professional judgement in the selection of material for building how to save energy in selection of a building assembly, building component or complete building system in terms of strength, stiffness and thermal performance. Strength is the measure of stress required to fracture the material. Stiffness is the rigidity of the material, the extent to which it resists deformation and dimensional stability.It is the ability of material to maintain its essential or original dimensions while being used for its intended purposes. Thermal performance is the capacity of building sections to provide resistance to changing climatic conditions. Thermal resistivity is the characteristic property of material which depends on density, porosity, moist content, fibre diameter, etc.,.

The energy efficiency of different building materials in relation to performance is given by comparing the energy costs of obtaining one unit of some property the designer is interested in using a range of materials for use of structural materials, it is the stiffness of the material which is of greater importance ${ }^{[3]}$. These costs are even higher than the range of structural costs, would be used because of other advantage of the durability they offer. Durability is defined as the service life of a material under given environmental conditions.

Increasing the efficiency of energy use in building- materials production is important for three reasons; its oblivious advantage of energy saving savings, making the durable building material made available at prices affordable by the poor and help in reducing the environmental degradation.

\section{STRENGTH, ENERGY AND THERMAL PERFORMANCE}

The embodied energy content of different materials help in identifying alternative materials and methods of construction. It is required to know how energy can be saved by selection of one building assembly, building component or complete building system rather than another when both alternative systems can satisfy all the simultaneous physical requirements- in terms of strength, stiffness, thermal performance and so on of the building.

Timber is the most energy efficient material for use in structures, being several times more efficient than steel or reinforced concrete. It also explains that use of aluminium for structural purposes is extremely expensive in terms of energy utilisation. Thus aluminium is preferred to other materials only for reasons like resistance to corrosion.

Materials used in external walls, claddings and insulation all need to be evaluated in terms of their thermal resistivity. The energy costs of different materials, per unit of thermal resistivity are shown in the table below

Table: 4.1 Energy requirement for one unit of stiffness of different materials ${ }^{[3]}$

\begin{tabular}{|l|l|l|l|l|}
\hline Material & $\begin{array}{l}\text { Elastic Modules } \\
(\mathrm{MN} / \mathrm{m} 2)\end{array}$ & $\begin{array}{l}\text { Density } \\
(\mathrm{Kg} / \mathrm{m} 3)\end{array}$ & $\begin{array}{l}\text { Energy } \\
(\mathrm{Kj} / \mathrm{Kg})\end{array}$ & $\begin{array}{l}\text { Energy cost of one } \\
\text { unit of E }\end{array}$ \\
\hline Timber(sawn) & 110000 & 500 & 1170 & 53 \\
\hline Mass concrete & 14000 & 2400 & 720 & 124 \\
\hline Brick & 30000 & 1800 & 2800 & 167 \\
\hline Reinforced Concrete & 2700 & 24000 & 8300 & 738 \\
\hline Steel & 210000 & 7800 & 43000 & 1598 \\
\hline aluminium & 70000 & 2700 & 238000 & 9180 \\
\hline
\end{tabular}

Table: 4.2 Energy requirement to obtain one unit of thermal resistivity of different materials (after Biggs)

\begin{tabular}{|l|l|l|l|l|}
\hline Material & $\begin{array}{l}\text { Resistivity,r } \\
(\mathrm{MK} / \mathrm{W})\end{array}$ & $\begin{array}{l}\text { Bulk density } \\
(\mathrm{Kg} / \mathrm{m} 3)\end{array}$ & $\begin{array}{l}\text { Energy } \\
(\mathrm{KJ} / \mathrm{Kg})\end{array}$ & $\begin{array}{l}\text { Cost of one unit } \\
\text { of resistivity } \\
(\mathrm{KJ})\end{array}$ \\
\hline Foamed polystyrene & 29.4 & 25 & 120000 & 74 \\
\hline Glass wool & 23.8 & 145 & 150000 & 91 \\
\hline Timber(soft wood) & 7.7 & 500 & 1170 & 110 \\
\hline Gypsum plaster & 2.7 & 1200 & 1800 & 800 \\
\hline Light weight concrete & 0.7 & 1200 & 720 & 1252 \\
\hline Mass concrete & 0.48 & 2400 & 720 & 3600 \\
\hline Glass & 0.95 & 2500 & 15000 & 3947 \\
\hline Rigid PVC & 6.2 & 1350 & 116000 & 25270 \\
\hline
\end{tabular}


The issue of choice of materials is much more complex . The trade-offs between energy costs of materials and energy savings has to be considered in the context of the life time energy

\section{EXPERIMENTAL STUDY:}

A study has been made on three proto type single room tenement buildings of $225 \mathrm{sft}$ facing east with uniform roof height and window area constructed with different materials at village Pargi of Rangareddy district, $90 \mathrm{~km}$ west of Hyderabad in the month of May.

Building 1. 200mm stone cement block masonary in cement and pointed with composite roof of $38 \mathrm{~mm}$ stone slabs+ $63 \mathrm{~mm}$ cement concrete.

Building 2. 230mm brick masonary in cement with $20 \mathrm{~mm}$ cement plaster inside and $12 \mathrm{~mm}$ cement plaster out side with $115 \mathrm{~mm}$ RCC roof.

The energy content of the building sections studied above is also calculated excluding the human energy consumed during manufacture and in construction.

Table: 5.1 Indoor and Outdoor surface temperatures of Roofing sections under study

\begin{tabular}{|c|c|c|c|c|c|c|c|}
\hline $\begin{array}{l}\text { Sl. } \\
\text { No. }\end{array}$ & $\begin{array}{l}\text { Section/Building } \\
\text { type }\end{array}$ & Material & $\begin{array}{l}\text { Material } \\
\text { qty } \\
\text { required }\end{array}$ & $\begin{array}{l}\text { Basic } \\
\text { Energy } \\
\text { content/unit }\end{array}$ & $\begin{array}{l}\text { Transportat } \\
\text { ion } \\
\text { Energy/unit }\end{array}$ & $\begin{array}{l}\text { Total } \\
\text { energy }\end{array}$ & $\begin{array}{l}\text { Energy } / \mathrm{sq} \\
\mathrm{m} \text { of plan } \\
\text { area } \\
\text { MJ }\end{array}$ \\
\hline \multirow[t]{6}{*}{1} & ROOFING & & & & & & \\
\hline & \multirow{4}{*}{$\begin{array}{l}\text { roof of } 38 \mathrm{~mm} \text { stone } \\
\text { slabs+ } \quad 63 \mathrm{~mm} \\
\text { cement concrete. }\end{array}$} & Cement & 9 & 400 & 42 & 3978 & \\
\hline & & Stone & 1cum & 100 & 140 & 240 & \\
\hline & & Metal & $1 \mathrm{cum}$ & 220 & 140 & 360 & \\
\hline & & Sand & 0.5 & 30 & 140 & 85 & \\
\hline & & \multicolumn{4}{|l|}{ Total } & 4663 & 222 \\
\hline \multirow[t]{4}{*}{2} & \multirow{3}{*}{$\begin{array}{ll}\text { Roofing } & \text { with } \\
115 \mathrm{~mm} \text { RCC } & \end{array}$} & Steel & $150 \mathrm{~kg}$ & 30 & 2.24 & 4836 & \\
\hline & & Cement & 15 & 400 & 42 & 6630 & \\
\hline & & sand & 1 & 30 & 140 & 170 & \\
\hline & \multicolumn{5}{|l|}{ Total } & 11636 & 554 \\
\hline
\end{tabular}

$* 2.8 \mathrm{MJ} / \mathrm{MT} / \mathrm{km}$ for $300 \mathrm{~km}=840 \mathrm{MJ} / \mathrm{MT}$ or $42 \mathrm{MJ} / \mathrm{bag}$ $\# 2.8 \mathrm{MJ} / \mathrm{ton} / \mathrm{Km}$ for $50 \mathrm{~km}=140 \mathrm{MJ}$

$\wedge 2.4 \mathrm{cum} / 1000 \mathrm{bricks}$ and $2.8 \mathrm{MJ} / \mathrm{km}$ for $50 \mathrm{~km}=336 \mathrm{MJ}$

$\$ 2.8 \mathrm{M} / \mathrm{MT}$ for $800 \mathrm{~km}=2.24 \mathrm{MJ} / \mathrm{kg}$ of steel
The thermal behaviour of the same building sections were studied for continuous 48 hours in the summer month of May to understand their thermal performance. Measurements were taken in the middle of the roof .

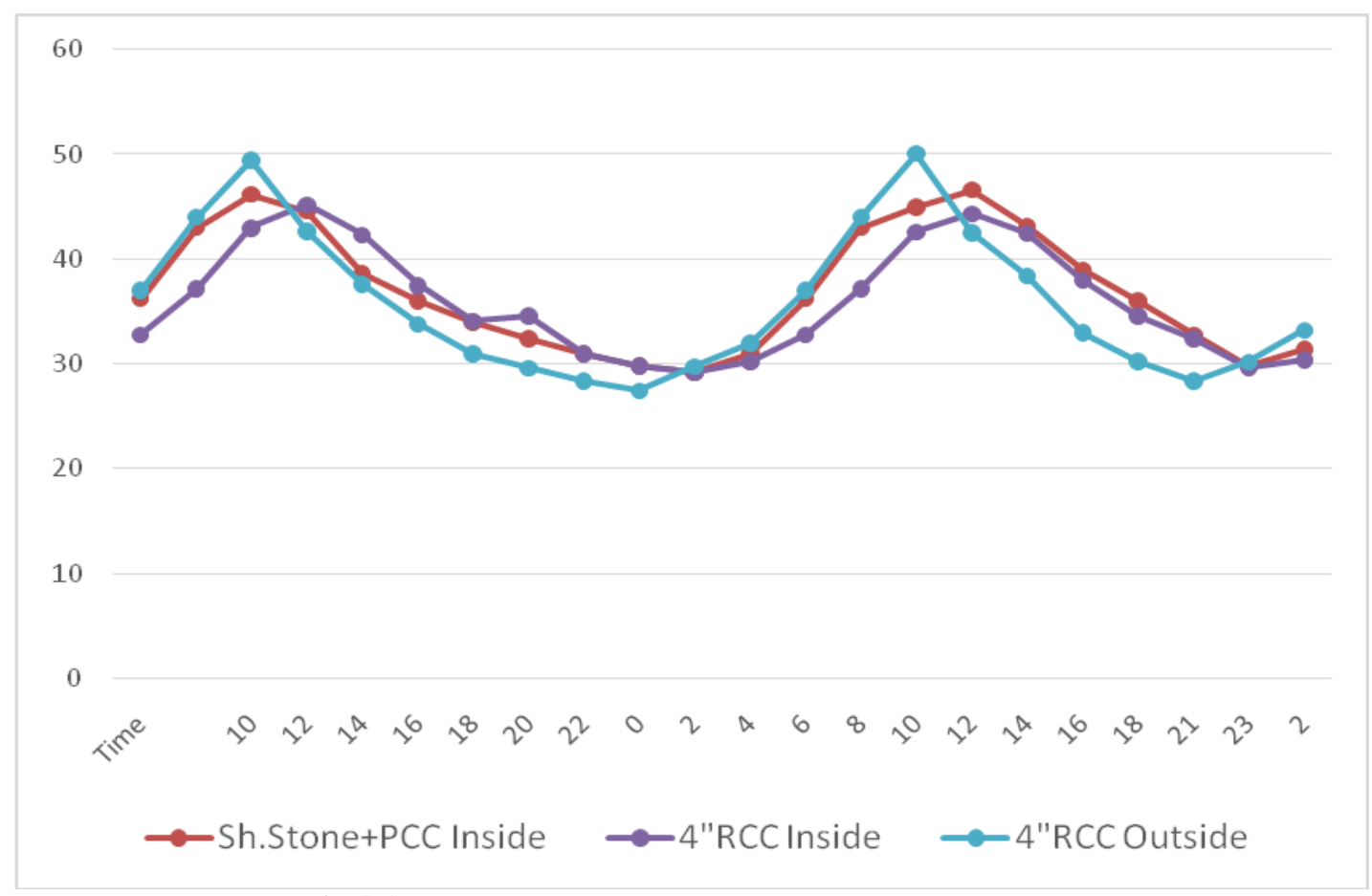

Fig 5.1 Indoor and outdoor temparatures of houses studied 
The thermal behaviour of the building sections are compared with the the final Thermal damping,D and Thermal performance index,

TPI is the indicator finally contributed to the indoor comfort, keeping surface colour, orientation, openings in a common environment.

Lower the TPI, better the Thermal performance of the section.

Table: 5.6 Thermal behaviour of different Roofing under study

\begin{tabular}{|l|l|l|}
\hline & $\begin{array}{l}\text { Stone } \\
\text { lab+concrete }\end{array}$ & RCC \\
\hline tis max & 46.6 & 45.2 \\
\hline tis min & 29.2 & 29.7 \\
\hline Ti & 17.4 & 15.5 \\
\hline tos max & 48.4 & 50 \\
\hline tos min & 27.9 & 27.5 \\
\hline To & 20.5 & 22.5 \\
\hline D & 5.74 & 31.11 \\
\hline TPI & $\mathbf{2 0 7 . 5}$ & $\mathbf{1 9 0}$ \\
\hline $\begin{array}{l}\text { Energy/sq m of plan } \\
\text { area in MJ }\end{array}$ & $\mathbf{2 4 0}$ & $\mathbf{5 6 1}$ \\
\hline
\end{tabular}

Table 1 of SP41 (S\&T)-1987, Handbook on Functional requirements of Buildings Part-II recommends minimum Thermal Performance Standards for walls and roofs for characteristic climatic zones in India and table 6 categorises the un conditioned buildings:

TPI $<75$ is rated as Good

$>75$ and $<125$ is rated as Fair

$>125$ and $<175$ is rated as Poor

$>175$ and $<225$ is rated as very Poor

$>225$ are Extremely poor.

All the roofs were tested for bending and deflection and found safe.

\section{CONCLUSION}

Construction consumes huge energy. Industrially produced construction material consume not only high energy but also produce pollution during production and transport. The housing stock made of such material becomes costly and un affordable by the poor. Sustainable construction can be done by using locally available construction materials. They found to be energy efficient, thermally comfortable, structurally safe and economical.

\section{REFERENCES}

[1]. People, settlements, environment and development, UN center for Human settlements (Habitat), Nairobi.

[2]. Technology in human settlements: role of construction, UN center for Human settlements (Habitat), Nairobi.
[3]. Energy for building- improving energy efficiency in construction and in the production of building materials in developing countries, UN center for Human settlements (Habitat), Nairobi, 1991

[4]. Sustainability, 2009,1,674-701, ISSN 2071-1050.

[5]. Energy conservation in the development and production of building materials, Mohan rai, 103-108, International workshop on Energy conservation in buildings, Roorkee, India. 1984.

[6]. SP 41(S\&T)-1987, Hand book on Functional requirements of Buildings, bureau of Indian standards, New delhi, 1988. 